\title{
Subsurface Characterization for Groundwater Management nearby the Unfinished Obelisk Archeological Site, Aswan Governorate, Egypt
}

\author{
Abdulaziz M. Abdulaziz \\ Mining, Petroleum and Metallurgical Engineering Department, Faculty of Engineering, Cairo University, Giza, Egypt \\ Email: amabdul@miners.utep.edu
}

How to cite this paper: Abdulaziz, A.M. (2019) Subsurface Characterization for Groundwater Management nearby the Unfinished Obelisk Archeological Site, Aswan Governorate, Egypt. Open Journal of Geology, 9, 839-860.

https://doi.org/10.4236/ojg.2019.911094

Received: September 15, 2019

Accepted: October 20, 2019

Published: October 23, 2019

Copyright $\odot 2019$ by author(s) and Scientific Research Publishing Inc. This work is licensed under the Creative Commons Attribution International License (CC BY 4.0).

http://creativecommons.org/licenses/by/4.0/

\begin{abstract}
Recently, the area located within the Unfinished Obelisk (UO) archeological site showed numerous seepages and accumulations of groundwater in a small pond located a few meters from the Unfinished Obelisk. The Supreme Council of Antiques sponsored integrated geological, geophysical, and hydrogeological studies to identify the possible sources of groundwater and the optimum technique to manage the groundwater flow system that may jeopardize this invaluable sculpture. The geological units and the prevailing structure have been studied in detail using Landsat imagery and field work over two consecutive seasons. The field studies indicated the development of several fault/joint systems oriented mainly ENE-WSW with clear indications of mineralization and intensive weathering effects along these fabrics. Several resistivity (vertical seismic profile and resistivity imaging) measurements extending down to at least $20 \mathrm{~m}$ depth and Radar imaging down to $10 \mathrm{~m}$ depth are gathered to investigate the extension of outcrop units and the dominant structures prevailing the near subsurface. Geophysical data indicated the development of at least three hydrostratigraphic units arranged from top to bottom as valley fill, fractured/weathered granite, and slightly fractured to massive granitic unit. In addition, the major faults mapped by resistivity images helped to locate several observation wells and a production well to test the transmissivity across the groundwater system. The results of a pumping test indicated very low aquifer conductivity and the development of an aquitard with preferential vertical flow at the study area. This enforces a local interference through a shallow underground drainage system with sump and pump to maintain low groundwater level at the UO-archeological site.
\end{abstract}

\section{Keywords}

Groundwater Management, Resistivity Imaging, Flow Regimes, Fractured 
Granite Aquitard, Unfinished Obelisk, Aswan

\section{Introduction}

Fractured crystalline basement typically develops extremely heterogeneous aquifer systems with significant anisotropy, especially where weathering effect prevails [1] [2] [3]. The capacity of fractures to groundwater flow changes over several orders of magnitude [4] [5] with flow paths normally vary between less than a meter and several kilometers long, while some fractured aquifers could be controlled by few fractures or faults [6] [7]. Such anisotropy results in a complex flow pattern that may involve a combination of preferential flow and diffuse piston flow [8] [9]. These aquifers are, therefore, known with vertical flow uncertainty [10], connectivity dependent to water level [9], and horizontal/vertical preferential flow paths [2]. Such a complexity naturally associates a rapid decrease in groundwater yield and storage with depth [11] [12]. Many studies have investigated fractured basement aquifers to appraise groundwater structure and functionality [13] [14] [15] [16], understand groundwater recharge [17] [18], evaluate the hydrogeochemical evolution of groundwater [19] [20], and place production water wells [21]. Regional scale hydraulic properties are preferably interpreted using numerical simulation of long-term groundwater fluxes and records of hydraulic heads distributed throughout the aquifer [22] [23]. Alternatively, well tests at small scale and upscaling the interpreted hydraulic properties are commonly applied as a substitute to the simulation studies, e.g. [24], but the consistency of the results is strongly dependent on the aquifer complexity [5]. Several hydraulic testing techniques have been developed to determine the hydraulic properties of fractured reservoirs using the responses induced by the precise perturbations within the aquifer [25]. These tests can assess a particular zone to determine the transmissivity of individual/closely spaced fractures [26] or evaluate the entire penetrated aquifer section to measure the effective transmissivity of all fractures [27]. In addition, well tests may resolve the vertical hydraulic properties testing the entire aquifer zone [28], or identifying the spatial connectivity of fractures in three dimensions if a particular zone within the aquifer is isolated by packers [6].

The Unfinished Obelisk (UO) archeological site represents a genuine quarry that enables invaluable scientific opportunity to know the techniques and fracture mechanics applied for obelisks production in ancient Egypt [29]. Obelisks represent the ancient skyscrapers that were created as a glory for the sun [30] and the majority of obelisks are made of red granite, especially the larger pieces. The UO has failed to complete because of the development of an unexpected fissures, not related to human mistakes, and therefore remained at the Aswan quarry connected only at its lower side [29]. It extends over $41.75 \mathrm{~m}$ length with a maximum width of $4.2 \mathrm{~m}$ at the base and the weight of approximately 1168 
ton. The site has attracted many researchers starting with [31] [32], who first excavated the UO-quarry [33]. A recent comprehensive geological and archaeological survey to the granite quarries of ancient Egypt is introduced by [34] [35] and identified many features including ancient inscriptions and fortifications. Despite the invaluable importance of this site, the extensive expansion in land development and urbanization associating the increase in population usually impose substantial adverse changes in groundwater regime that may jeopardize such important archeological sites [36] [37] [38]. These changes might be revealed, as represented at the UO-site, in form of rising in groundwater level and the development of local problems such as groundwater mounds, groundwater ponds/water-logging, and the reversal of flow direction [39]. Several geophysical techniques, especially resistivity and Radar imaging are applied to characterize the subsurface architecture and the prevailing groundwater system, e.g. [40] [41] [42]. The present study aims at integrating geological, geophysical, and hydrogeological studies to help understanding the groundwater dynamics and describe flow patterns in the fractured/weathered granite aquifer at the vicinity of the UO-archeological site. This includes detailed field work with satellite image analysis, resistivity and Radar data acquisition, drilling test holes and lithological description, and conducting a pumping test with geochemical analysis of groundwater samples. The results of this analysis helped selecting the optimum scenario for controlling the groundwater system at the proximity of the UO-archeological site.

\section{Methods}

The present study encompasses integration of geological, geophysical, and hydrogeological investigations to evaluate the near-surface groundwater system at the proximity of the UO.

\subsection{Geological Study}

The geological studies involve a detailed fieldwork to the granitic bodies exposed at the UO-site and continued south to the Aswan reservoir (Khazan Aswan), east to the Nile River and west to the Kima drain. This encompasses mapping the dominant rock units and the structural features particularly those prevailed Aswan granite and the other basement rocks. A Landsat image of the study area is used for mapping geological and structural features. Both linear and planar fabric elements are described and mapped in details to outline the possible flow path of groundwater system. Alternatively, the structural analysis of the field measurements constructed an Ellipsoid Stress Model on 3D Stereonet using Geoorient-Dips 5.6 software.

\subsection{Geophysical Investigations}

Geophysical studies are applied to reveal the prevailing subsurface architecture, determine the depth to groundwater level, and map the possible structural fea- 
tures concealed below the soil zone. All geophysical measurements are located at the proximity of the UO and involve Vertical Electrical Sounding (VES), Resistivity imaging, and Radar imaging survey. Figure 1 shows the location of the geophysical measurements at the investigated site. The data of three VESs are acquired using Schlumberger configuration with SYSCAL-PRO unit (IRIS) and a maximum cable length of $100 \mathrm{~m}$ to enable a depth of investigation within $20-30$ $\mathrm{m}$. Datum levels are determined using a series of consecutive increase to electrode separation [43], starting with a small electrode spacing $(2,3,5$, and $10 \mathrm{~m})$, followed by gradual increase in spacing for the subsequent measurements. The measurement geometry is designed similar to the configuration described by reference [41] and [44]. To maintain an acceptable contact with minimal soil effect that keep the contact resistance below $2000 \Omega$, a saline solution is prepared for dispense around individual electrodes. A lithium battery reserved the power supply to the measurement system and field data acquisition is accomplished using armored insulated cables.

The geographic location of VESs and other ground control points (GCP) are precisely determined with a hand held GPS unit, Garmin e-Trex that achieved a horizontal accuracy within $\pm 0.5 \mathrm{~m}$. Alternatively, the altitudes and coordinates of the mid-point for each VES survey-line are confirmed, for accuracy and data consistency, with the available topographic maps, Google-earth maps, and a total station survey conducted at the study area using a local datum. Similarly, a 2D resistivity image of $72 \mathrm{~m}$ long is compiled using a series of CVES measurements with dipole-dipole electrode configuration and electrode spacing of $3 \mathrm{~m}$ to maintain a minimum depth of investigation within $20 \mathrm{~m}$. The acquired data of both VES and CVES are reviewed and filtered to omit noisy measurements before applying $1 \mathrm{D}$ and $2 \mathrm{D}$ inversion to convert the apparent resistivity measurements into true resistivity, bed thickness and depth of alternating layers. With inversion, a 2D model with large number of cells of definite resistivity values is initiated and the apparent resistivity to this model is calculated and subsequently

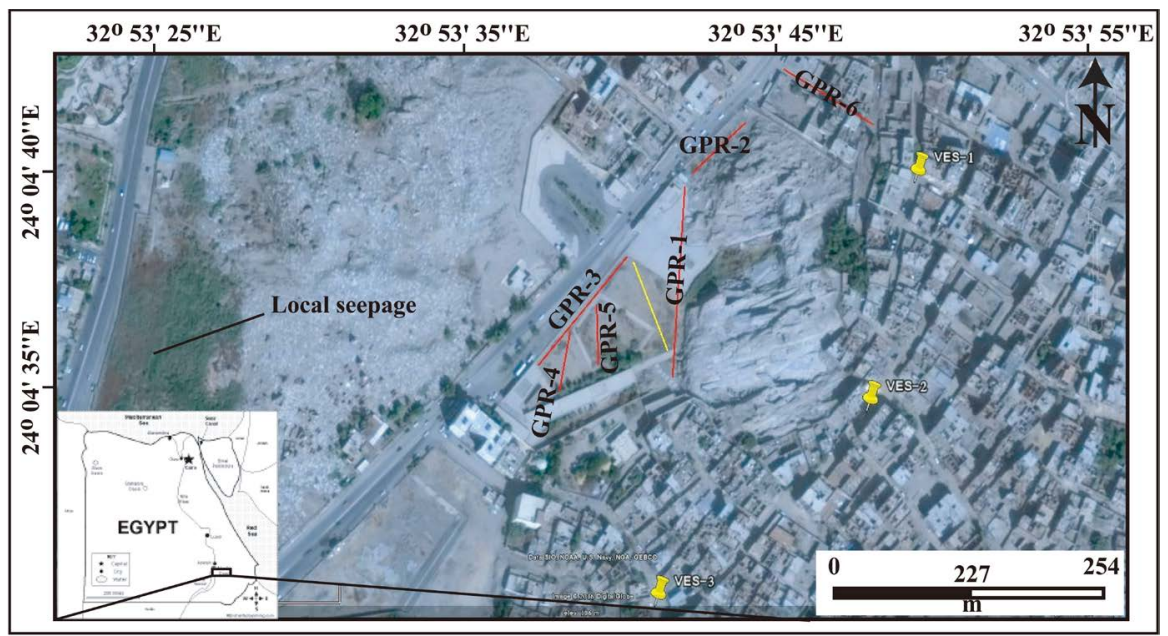

Figure 1. Location map of the Unfinished Obelisk area showing the sites of geophysical survey, the yellow line indicates the location of resistivity image. 
compared to the measured resistivity. The RMS-Error technique is applied to evaluate the match of each calculated resistivity to the corresponding measured value. Then, the resistivity cells are changed recursively and each time the RMS-Error is calculated. These processes continued until the calculated RMS-Error approaches a predefined threshold that defines the best fit between apparent and measured resistivity. This match identifies a representative distribution of resistivity in subsurface that characterize rock unit distribution. Figure 2 shows the

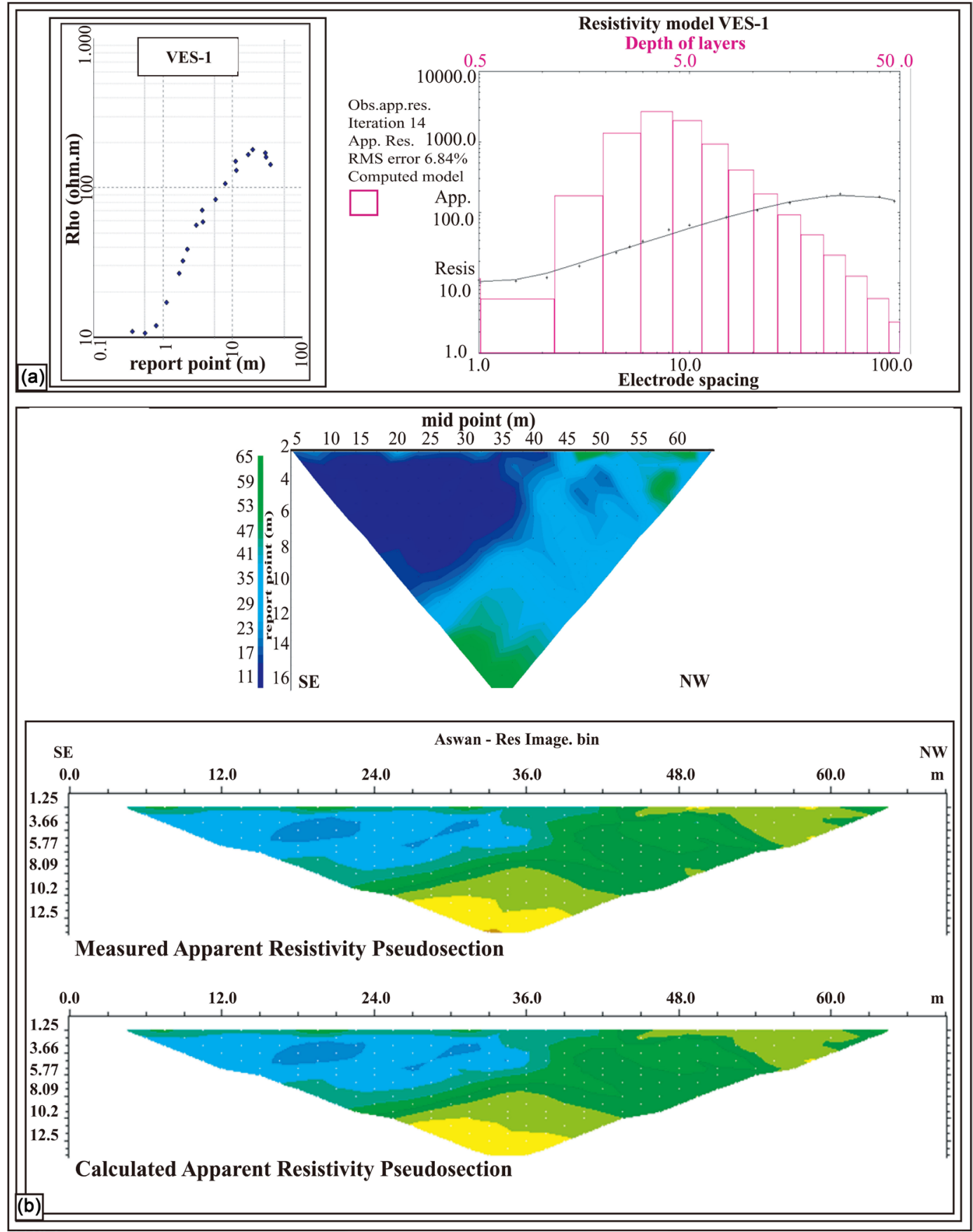

Figure 2. The inversion stages applied to the 1D-resistivity data (a) and the resistivity image (b) acquired at the UO-site. 
inversion results (RMS-Error $\approx 2.0 \%$ ) that developed $1 \mathrm{D}$ resistivity data (a) and $2 \mathrm{D}$ image (b) of subsurface true resistivity distribution. Resistivity inversion is completed using RES2DINV software (Locke, 2006). Six Radar lines (Figure 1) have been acquired using X3M-Radar System with $100 \mathrm{MHz}$ antenna to reveal the important geologic features down to $10 \mathrm{~m}$ depth. REFLEXW software has been applied to the raw field data to remove noisy signals, recover signal deterioration with depth, and apply several data averaging to improve reflectors continuity and the overall quality of the radar image. Figure 3 presents the Radar section at line 5 (Figure 1) before (left) and after (right) data processing, as an example for data quality improvement using REFLEXW package.

\subsection{Hydrogeological Study}

The hydrogeological study involves detailed site investigation and changes in landuse/landcover at the nearby regions, particularly those located up dip. Several seepage sites and the water body located at the study area are visited and evaluated using Landsat data and local inhabitants' interview. Based on geological and geophysical investigations, six test holes are drilled using rotary drilling techniques and completed as piezometers. These boreholes helped confirming the subsurface architecture delineated by geological and geophysical investigations and also monitoring the groundwater system. In addition, a production well (Asn-P) is drilled at the main fault gouge to sample groundwater for geochemical analysis and test a possible local drainage to the exposed seepage through pumping and aquifer stress. A pumping test over more than 7 hours is completed with a pumping rate of $10 \mathrm{~m}^{3} / \mathrm{h}$ and the aquifer stress is monitored at the nearby piezometers Asn-1, Asn-2, and Asn-3. Groundwater sampling for laboratory analyses is accomplished after pumping the stagnant water out and the produced water is filtered through $0.45 \mu \mathrm{m}$ filters and subsequently preserved in

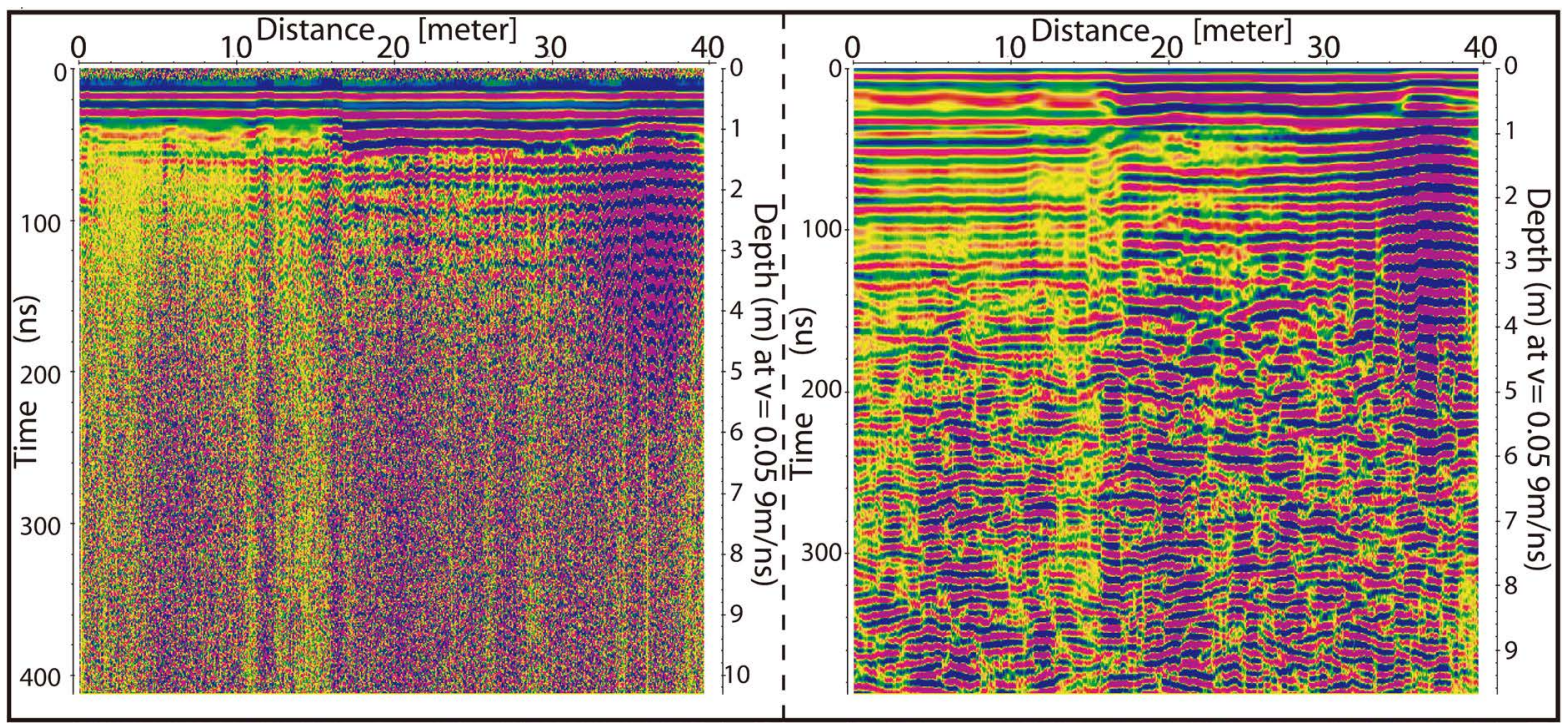

Figure 3. An example to Radar data (line 5 before "left" and after "right") processing to improve the data quality using REFLEXW package. 
clean high-density polyethylene (HDPE) bottles. The samples are separated into two aliquots, the first is kept in the original chemical condition and the second aliquot is stabilized with ultra-pure $\mathrm{HNO}_{3}$ to a $\mathrm{pH}$ less than 2. Major cations $\left(\mathrm{Na}^{+}, \mathrm{K}^{+}, \mathrm{Ca}^{2+}\right.$, and $\mathrm{Mg}^{2+}$ ) and some trace elements (e.g. $\mathrm{Fe}^{2+}, \mathrm{Mn}^{+}, \mathrm{Pb}^{2+}, \mathrm{Cu}^{2+}$, and $\mathrm{Zn}^{2+}$ ) are geochemically analyzed using the filtered/acidified aliquot. The other filtered/un-acidified aliquot is used for the analysis of major anions $\left(\mathrm{Cl}^{-}\right.$, $\mathrm{SO}_{4}^{2-}, \mathrm{HCO}_{3}^{-}$, and $\mathrm{CO}_{3}^{2-}$ ). The accuracy of the chemical analysis is evaluated using cation-anion charge balance and has fallen within the allowable errors. All chemical analyses are performed at the Soil, Water and Environment Research Institute (SWERI), Agricultural Research Center, Ministry of Agriculture and Land Reclamation, Giza.

\section{Results and Discussion}

\subsection{Structural Analysis}

The UO-area is affected by a group of faults and joints cutting each other and oriented to numerous directions (ENE-WSW, NW-SE, N-S, and E-W) with ENE-WSW representing the dominant direction that goes parallel to the elongation of the UO (Figure 4). The fault/joint intersections might not appear at the surface and most fault plains/intersections are filled with mineralization of pegmatites or quartz resulting in impermeable media. This mineralization appeared intact to ancient Egyptians, and inconsequence started cutting the UO parallel to ENE-WSW direction despite the presence of the N-S joints filled with quartz mineralization. Isolation/engraving of the UO from the main granite body is ceased due to the displacement induced by a WSW dipping joint initiated below the obelisk that led to few centimeters gravity settlement to the southern part of the obelisk along an N-S fracture. The ENE-WSW fault and joint systems prevailed the granitic intrusion of the study area with roughly vertical and inclined striations and slickensides dominated the granitic blocks, indicating relatively dextral-slip along the oblique displacements (Figure 5). Such a movement experienced structural inversion to a transpression movement that resulted in a pop-up structure at some granitic blocks, such as the UO-area, and qualified the core of these blocks as a good site to quarry obelisks and other sculptures. However, the surrounding areas to the north, northwest and southeast are strongly affected by many faults of different directions resulting in lower topographic features with strong weathered sections of important local seepages as presented at the Fatimid Cemetery (Figure 1). Field observation confirmed the excessive engravings at the pop-up granitic block that resulted in topographic lows and overtime formed a surface and groundwater drainage basin with growing bushes and swamps plants.

Generally, the strike-slip tectonics in the study area induced dextral displacements at the NW-SE and E-W faults and sinistral displacements at the N-S and NE-SW faults. Alternatively, the intersection of the dominant ENE-WSW faults with both N-S and NW-SE faults (gray areas in Figure 4) formulated topographic 


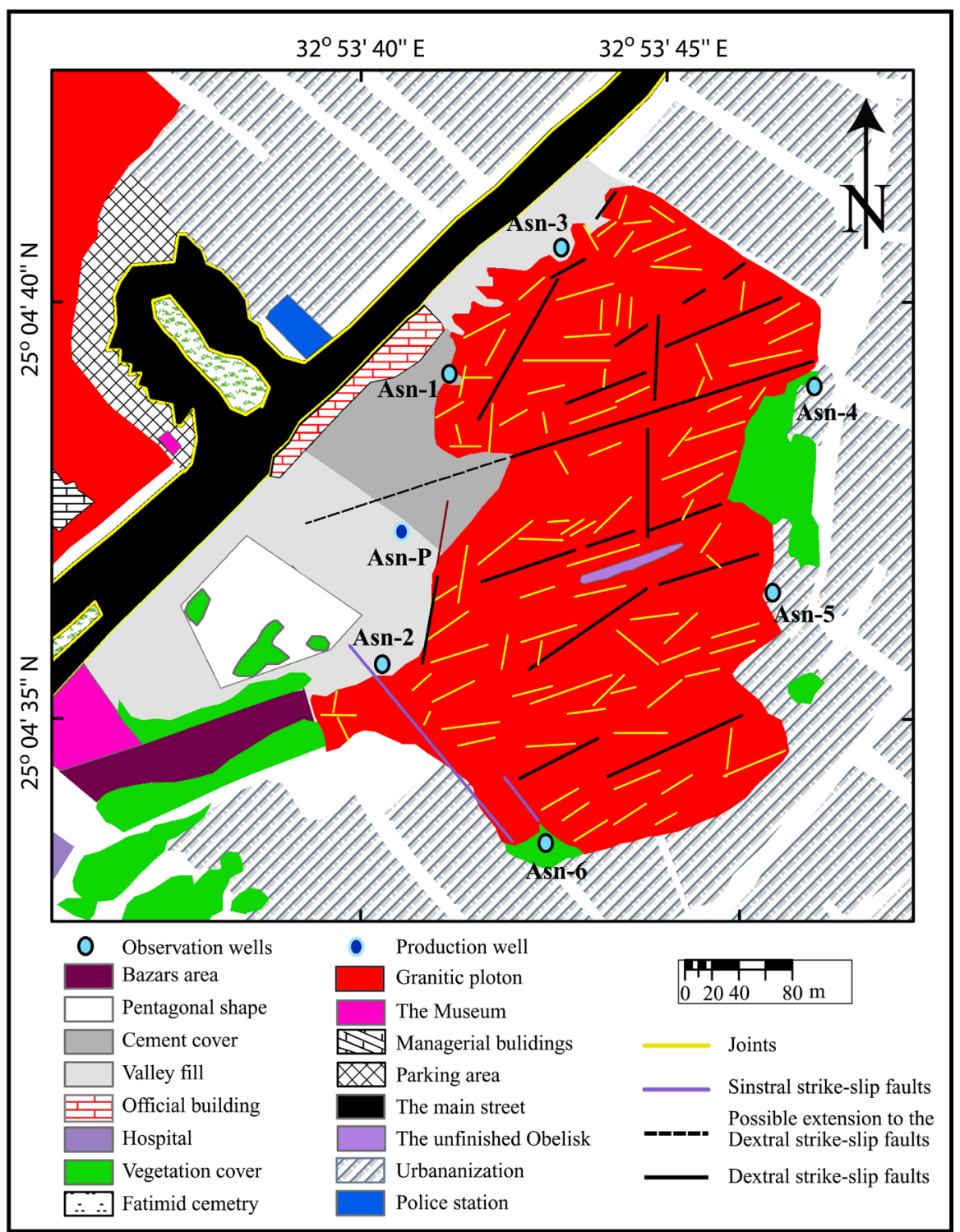

Figure 4. A physiographic map showing the main land-cover and geological features together with the location of the drilled boreholes.

lows such as those located to the west of the UO-granitic block that act as the main discharge basin to the surrounding topographically highlands. The NW part of the study area is mainly affected by intersection of NNE-SSW and N-S with ENE-WSW and NW-SE fault/joint systems that obviously resulted in crushing the granitic body and the development of sparse seepages at this area. The structural analysis confirmed by field observation indicated dextral strike-slip movements along the NW-SE fault and its branches resulting in the static equilibrium of the granitic blocks at this area. Similarly, the southwestern part is affected by a NW-SE fault that delineates the boundary of the granite intrusion (Figure 4). The fault/joint measurements from the field work and satellite images are analyzed and projected to the stereonet using Geoorient- 6 version-5. Figure 6(a) shows data frequency-azimuth diagram that confirmed the 

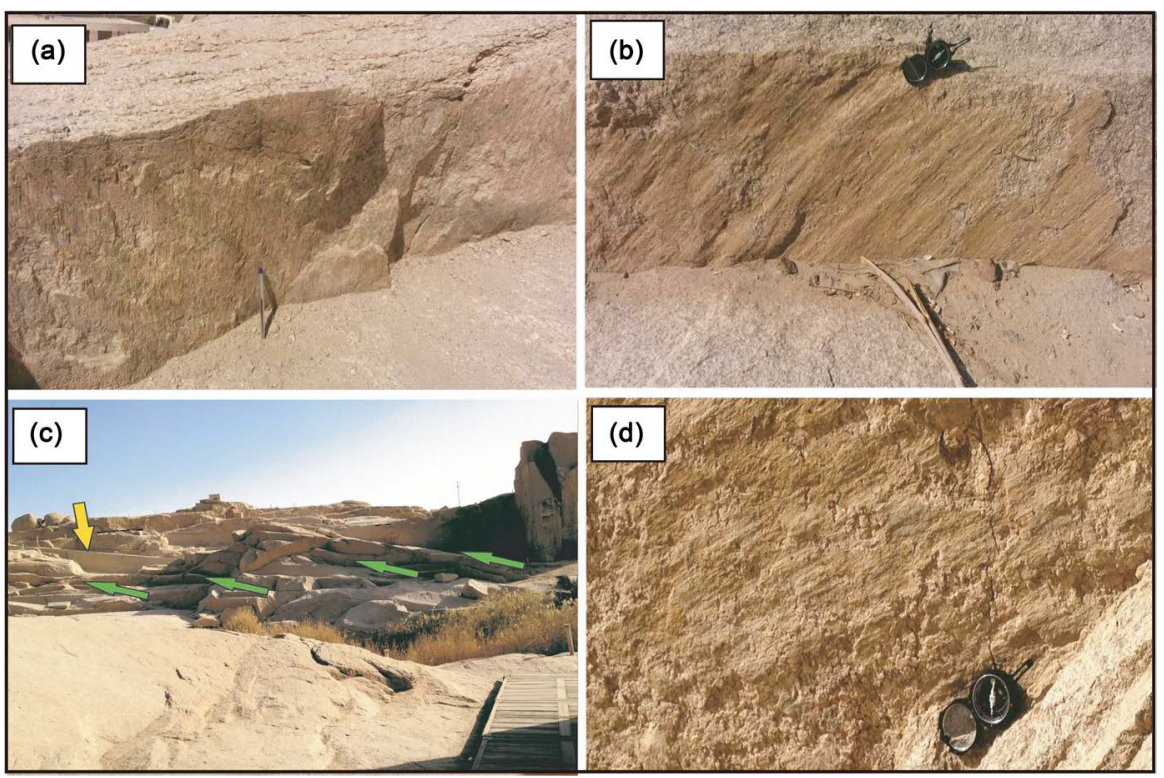

Figure 5. Striations and slickensides dominated the granitic blocks nearby the UO-site. (a) The vertical striations developed along the fault plain indicating vertical displacement asscoiating a normal fault; (b) The inclined striations and slickensides indicate relatively dextral strike-slip displacements along the ENE-WSW faults; (c) Several strike slip faults oriented NW-SW (yellow arrow) together with the ENE-WSW strike slip to oblique faults (green arrows); (d) The association of slickensides and striations features along the plain of an oblique fault.

field observations on directions and dominant structural features. Figure 6(b) presents the plot of the fault and joint measurements on the stereonet, which indicated that ENE-WSW faults strike $\mathrm{N} 60^{\circ} \mathrm{E}$ with average dip of $75^{\circ}$ dominantly towards NNW. On the contrary, the NW-SE features strike $\mathrm{N} 51^{\circ} \mathrm{W}$ with average dip angle of $78^{\circ}$ to the NE, while the NNE-SSW features strike $\mathrm{N} 5^{\circ} \mathrm{E}$ with dominant dip angle of $78^{\circ}$ towards WNW. Finally, the E-W features are dominantly dipping at $82^{\circ}$ towards the North direction but sometimes show steeper angles $\left(\sim 87^{\circ}\right)$ to the South. The principle stress in the study $(\sigma 1)$ can be identified by plotting the shearing stresses along the principle fault (M) oriented ENE-WSW, and the secondary directions-oriented NNE-SSW (R') and NW-SE (R) (Figure $6(c)$ ). Field observation and the structural analysis indicate that $\sigma 1$ is approximately oriented $\mathrm{N} 23^{\circ} \mathrm{W}-\mathrm{S} 32^{\circ} \mathrm{E}$ as presented on ellipsoid stress model (Figure $6(\mathrm{c}))$.

\subsection{Geophysical Data Interpretation}

Three VESs have been acquired using Schlumberger configuration to target a total depth of $25-30 \mathrm{~m}$, and the inversion result of the apparent data to true resistivity subsurface model is presented in Table 1. Generally, five resistivity zones have been identified in the inverted VESs that could be lumped into four zones as interpreted in VES-1. The surface layer is relatively thin $(0.4-1.5 \mathrm{~m})$ with low resistivity that fall between $4.7-11.9 \mathrm{Ohm} \cdot \mathrm{m}$ and coincides with the soil zone of wet rubble and heap. The underlying layer is also thin $(0.5-1.2 \mathrm{~m})$ 


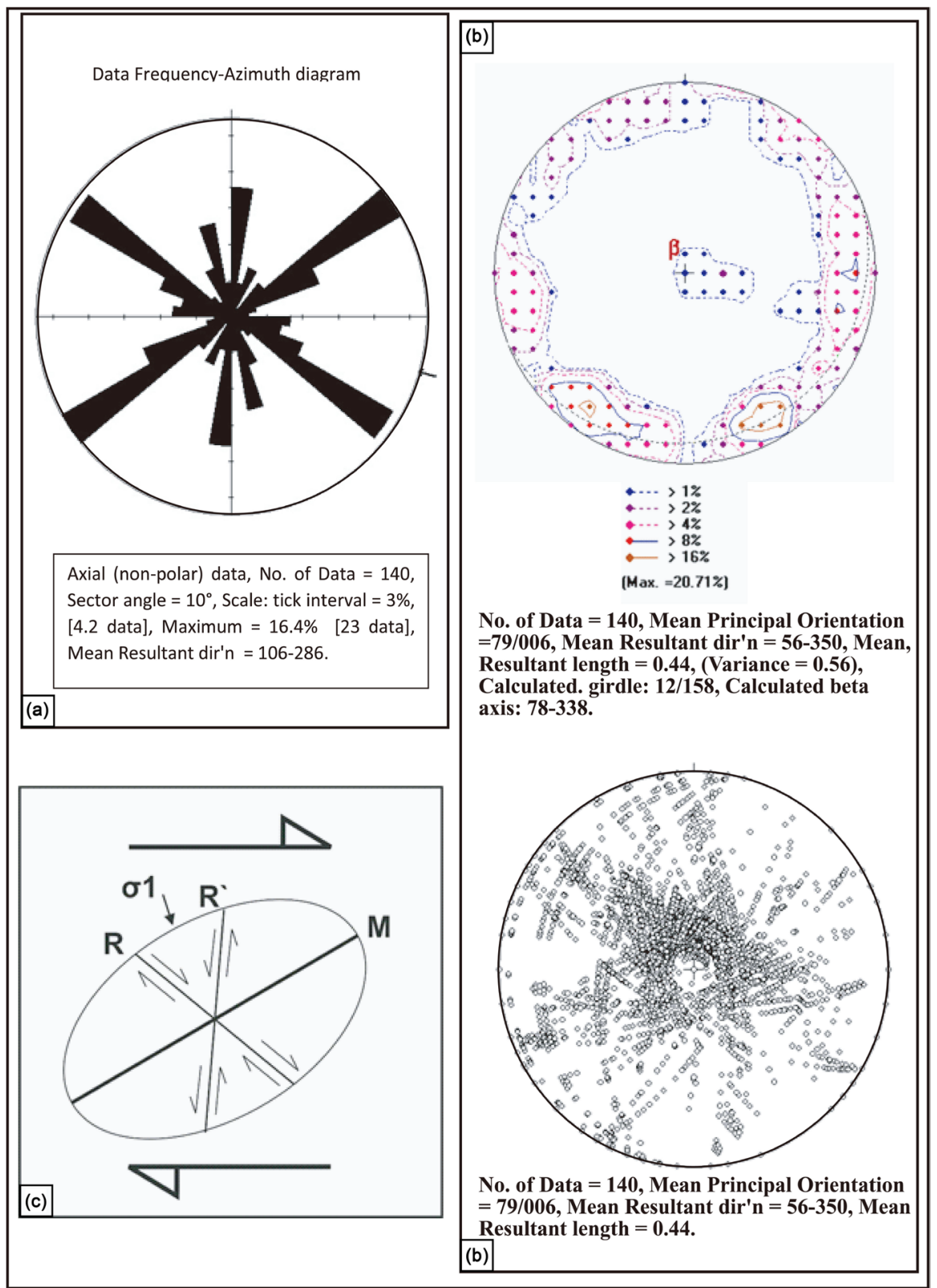

Figure 6. The structural analysis of the measured data showing the frequency-azimuth diagram “(a)", the stereonet projection “(b)", and the ellipsoid stress model “(c)”.

but shows relatively high resistivity $(42.5-147.3 \mathrm{Ohm} \cdot \mathrm{m})$ and typically represents the dry rubble and breaking stones (Table 1 ). The third resistivity layer is significantly resistive $(1210-1870 \mathrm{Ohm} \cdot \mathrm{m})$ and appears to extend through the study area with thick profile $(3.0-4.9 \mathrm{~m})$ representing the fractured to weathered granite. This layer is generally dry, but where the resistivity significantly falls between 7 and $15.5 \mathrm{Ohm} \cdot \mathrm{m}$ changes into a water-saturated interval (typically $3.5 \mathrm{~m}$ thick, Table 1). The basal resistivity unit showed high resistivity (789 and 1287 $\mathrm{Ohm} \cdot \mathrm{m}$ ) character that represents the weakly fractured to massive granite and extends deeper than the investigation depth of the present study (Table 1). This indicates a total weathered section of approximately $7.5 \mathrm{~m}$ thick and an apparent 
Table 1. The true resistivity model interpreted from the VES data acquired near the UO-archeological site in Aswan.

\begin{tabular}{|c|c|c|c|c|}
\hline \multirow{2}{*}{ Layer No. } & \multirow{2}{*}{ Resistivity $(\mathrm{Ohm} \cdot \mathrm{m})$} & \multicolumn{2}{|c|}{ Depth (m) } & \multirow{2}{*}{ Thickness (m) } \\
\hline & & From & To & \\
\hline \multicolumn{5}{|c|}{ Aswan-VES-1 (Approx. Ground Level: 113 m) } \\
\hline 1 & 4.7 & 0 & 0.6 & 0.6 \\
\hline 2 & 47.6 & 0.6 & 1.1 & 0.5 \\
\hline 3 & 1868.4 & 1.1 & 7 & 5.9 \\
\hline 4 & 15.5 & 7 & - & - \\
\hline \multicolumn{5}{|c|}{ Aswan-VES-2 (Approx. Ground Level: 124 m) } \\
\hline 1 & 8.1 & 0 & 0.4 & 0.4 \\
\hline 2 & 140.9 & 0.4 & 1 & 0.6 \\
\hline 3 & 1213.1 & 1 & 4 & 3 \\
\hline 4 & 12.1 & 4 & 7.4 & 3.4 \\
\hline 5 & 1287.2 & 7.4 & - & \\
\hline \multicolumn{5}{|c|}{ Aswan-VES-3 (Approx. Ground Level: $113 \mathrm{~m}$ ) } \\
\hline 1 & 11.9 & 0 & 1.5 & 1.5 \\
\hline 2 & 42.4 & 1.5 & 2.3 & 0.8 \\
\hline 3 & 147.3 & 2.3 & 2.7 & 0.4 \\
\hline 4 & 7.8 & 2.7 & 6.6 & 3.9 \\
\hline 5 & 789.2 & 6.6 & - & - \\
\hline
\end{tabular}

water-saturated section detected by VES between 6.6 and $7.4 \mathrm{~m}$ thick.

A $2 \mathrm{D}$ resistivity profile of $72 \mathrm{~m}$ length and extending SE-NW, is acquired using dipole-dipole configuration with $3 \mathrm{~m}$ spacing to explore for groundwater accumulation and the prevailing geologic structures down to $20 \mathrm{~m}$ depth. Figure 7 presents the vertical and horizontal distribution of resistivity units along the resistivity profile acquired perpendicular to the dominant ENE-WSW structures, which represents the expected main flow path for groundwater movement. Figure 7 indicates the development of three resistivity units; the upper low resistivity unit followed by an intermediate resistivity unit and underlined by a relatively high resistivity unit. The upper resistivity unit represents the valley deposits of sand mixed with silt and clay with resistivity between 3 and $20 \mathrm{Ohm} \cdot \mathrm{m}$. This unit increases in thickness towards the NW that follows the direction of the step fault-throws developed in this area. The intermediate unit showed a resistivity of $60-184 \mathrm{Ohm} \cdot \mathrm{m}$ that varies in thickness between $2 \mathrm{~m}$ and $5 \mathrm{~m}$ and corresponds to the strongly weathered/fractures granite of partial or total water saturation. The lower unit represents the granite of moderate to minor weathering/fracturing effects and typically reports a resistivity over $184 \mathrm{Ohm} \cdot \mathrm{m}$. This unit is characterized by an obvious subsurface irregularity as a result of the development of numerous normal faults of step patterns. These faults occur near surface at the SE, 


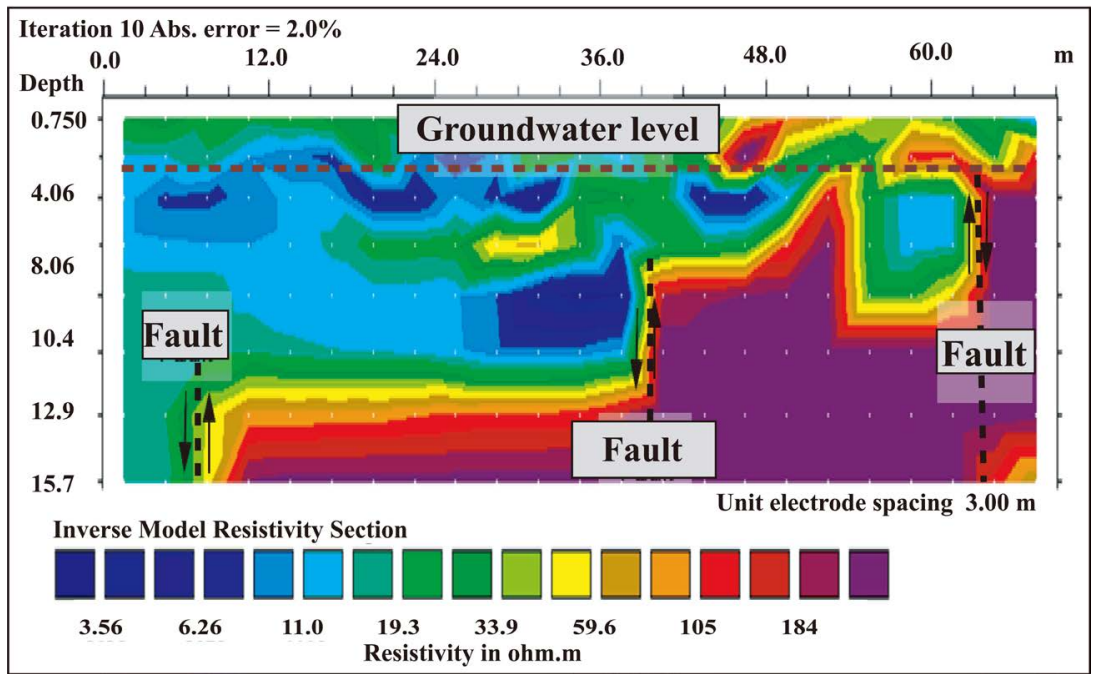

Figure 7. The vertical and horizontal distribution of resistivity along the resistivity image acquired perpendicular to the dominant ENE-WSW structures.

increase gradually in depth to $12 \mathrm{~m}$ at the mid profile, and fall below $16 \mathrm{~m}$ at the NW part of the profile (Figure 7). The fault-throw typically falls between $3 \mathrm{~m}$ and $6 \mathrm{~m}$ but may exceed $8 \mathrm{~m}$ as anticipated at the NW part of the resistivity profile. Such subsurface architecture suggests that the NW part of the resistivity profile is likely marking the development of a major groundwater drainage system following a major fault concealed under the asphaltic road bounding the UO-site to the west. Generally, this fault displaced the bulk granitic intrusion into two main parts; the UO-block and the Fatimid Cemetery block that contemporaneously displaced along a dextral slip movement that support the structural analysis of the area.

The Radar images (Figure 8) showed excellent signals at the surface of all images that typically extend down to $2 \mathrm{~m}$ depth and generally represent the valley deposits of sand and silt. These signals deteriorate with depth to moderate or weak signals depending on the predominant water saturation and intensity of weathering/fracturing of bed rock. But, in all cases the depth of penetration rarely exceeds $9 \mathrm{~m}$. The GPR-1 line indicates the presence of alluvial cover of 0.7 $\mathrm{m}$ thick at the SW that progressively increases to $5 \mathrm{~m}$ thick at the middle and NE parts. Generally, massive granitic bodies and thick sedimentary cover are represented by the continuous reflections while fractured and weathered granites are likely existing where weak reflections prevailed (Figure 8). All Radar images indicate a possible groundwater level at $1.0-1.25 \mathrm{~m}$ depth as represented by a common reflection pattern of dark tone that may rebound near surface at seepage sites (Figure 8). Comparing GPR-2 to GPR-1 profiles, the strong signals characterize the development of massive granitic bodies at the middle part while the terminal parts show significantly fractured units that extend down to the bottom of the section and characterize the fractures associating the major faults. The GPR-3 profile is gathered parallel to the main fault line separating the granitic pluton into two masses and most likely presents a thick local sedimentary-fill 


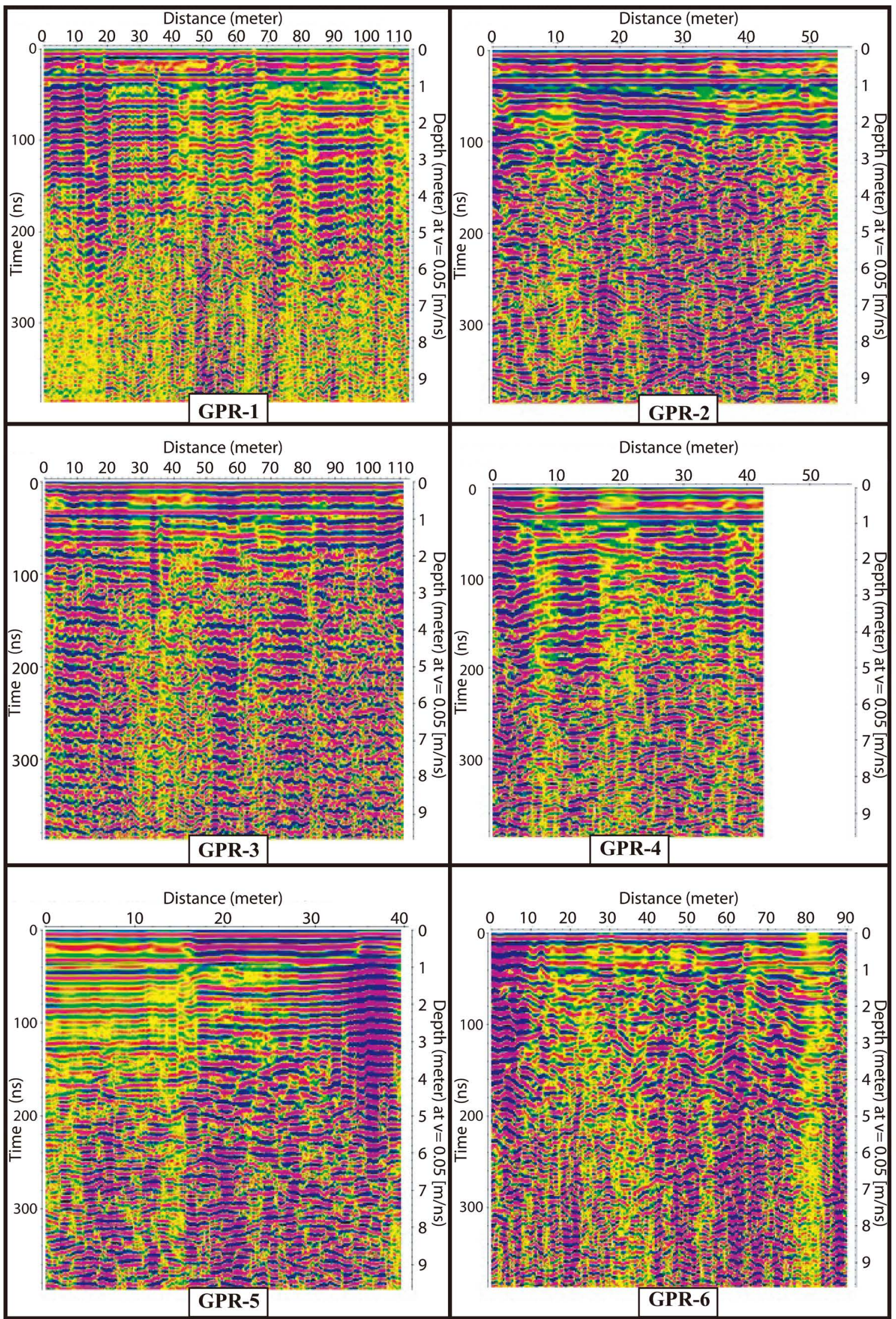

Figure 8. The final Radar images acquired along the profiles shown in Figure 1. 
saturated with groundwater. The dominant texture prevailing this profile remains consistent except for some spurious artifacts introduced as the antenna becomes closer to the metal fence of the site (Figure 8). The GPR-4 and GPR-5 profiles are gathered at the central part of the preserved site and appear predominated with the sedimentary-fill over fractured granite that appears highly weathered in GPR-4 as indicated by the severe signal attenuation. Finally, the GPR-6 profile presents a thin shallow sedimentary cover that hardly exceeds $1 \mathrm{~m}$ thick followed by highly weathered granitic section with important attenuations attributed to the municipal utilities running parallel to this profile (Figure 8).

\subsection{Hydrogeological Setting}

Geological and geophysical investigations indicated the presence of a small water pond covered by intensive vegetation at the proximity of the UO. This pond initiated in 2002 and the water level increases over time, but oscillates annually with high level in summer and low level or complete disappearance in winter. Over two-winter site visits, the water level of the pond raised almost $50 \mathrm{~cm}$. In addition, numerous irregular seepages within and around the UO-site have been observed and are topographically located above and below the level of the water pond such as the excessive seepage prevailing the Fatimid Cemetery. Such water accumulations are probably related to the northern and eastern urbanization located up-dip the important archeological site. Other possible sources include the Kima drainage channel that cuts directly in the granitic masses of the main intrusion, the unattended flood irrigation to the neighboring vegetation cover (Figure 9(a)), and the seldom rainfall that rarely formulates a storm (Figure 9(b)). Another important, but indirect, source is the Nile River water, as the water pond at the trough disappears and reappears with low and high Nile seasons respectively, indicating a direct relationship. Based on geological and geophysical studies, six observation wells (Asn-1 to Asn-6) and a production well (Asn-P) are drilled, and the well details presented in Table 2 with the hydrostratigraphic units of these wells compiled in Figure 10. Generally, the drilled sections indicated the presence of a land fill layer that is dominantly less than $1 \mathrm{~m}$ thick but reported over $15 \mathrm{~m}$ in Asn-6 well (confirms VES-3 measurements, Figure 8) that is not completed to the target depth due to severe drilling fluid losses. This layer overlies a layer of weathered/fractured granite of relatively medium hardness and extends down between $5 \mathrm{~m}$ and $10 \mathrm{~m}$ depth as depicted in wells Asn-2 and Asn-5 (Figure 10) and confirms the resistivity and radar data interpretation at this area. The slightly fractured to massive granite progressively appears near surface on approaching the intrusive block as reported in Asn-1, Asn-4, and Asn-5 well. Massive granitic boulders could be also found embedded in the valley fill or fractured granite unit as those seen in Asn-3 well and imaged in GPR-2 section (Figure 8 and Figure 10).

The groundwater level (measured relative to the sea level) around the UO-archeological site falls close to $90 \mathrm{~m}$ at the eastern part as reported in Asn-4 


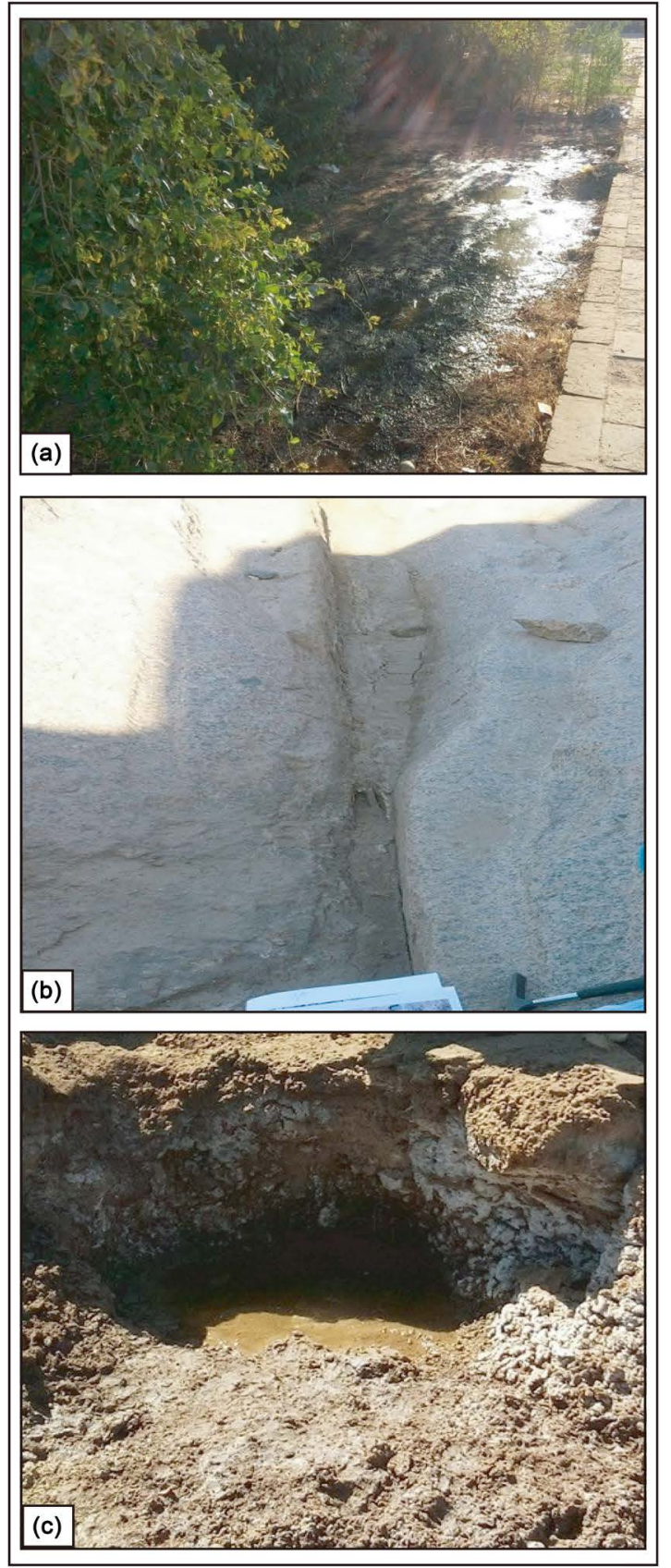

Figure 9. Some important surface features influencing the hydrogeological regime in the study area; "(a)" unattended flood irrigation, "(b)" the seldom rainfall effects along a fault with developed pegmatite mineralization, and "(c)" a small pit in the valley fill with perched water level.

Table 2. The basic well information for the test boreholes drilled at the proximity of the UO site.

\begin{tabular}{cccccccc}
\hline Piezometers & Asn-1 & Asn-2 & Asn-3 & Asn-4 & Asn-5 & Asn-6 & Asn-P \\
\hline Ground level (m) & 84.1 & 84.19 & 84.2 & 93.5 & 100 & 106 & 84.28 \\
Depth to water (m) & 2.4 & 2.85 & 1.6 & 4.02 & 9.5 & - & 2.83 \\
Groundwater level (m) & 81.7 & 81.34 & 82.6 & 89.4 & 90.8 & - & 81.45 \\
\hline
\end{tabular}




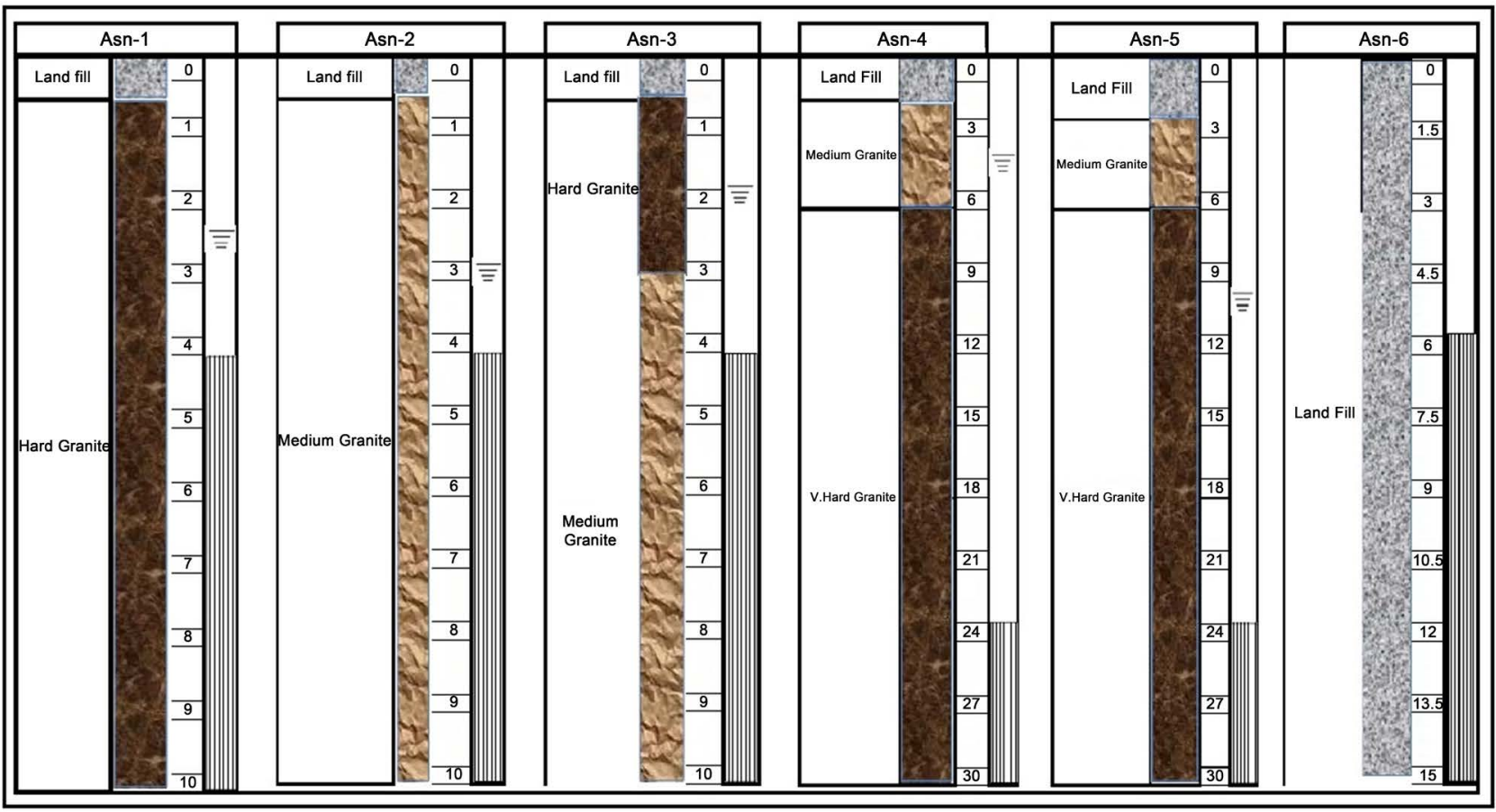

Figure 10. The hydrostratigraphic units and the groundwater level observed in the drilled boreholes shown in Figure 4.

and Asn-5 piezometers and falls steeply over less than $200 \mathrm{~m}$ distance to $\sim 80.0 \mathrm{~m}$ following the dominant topography of the area (Table 2). Alternatively, at the south western part the groundwater level reported $81.34 \mathrm{~m}$ (Asn-2) and increases northward to $82.5 \mathrm{~m}$ as measured at (Asn-3), Table 2. Based on the data interpretation of the resistivity image (Figure 7), a water production well (Asn-P) is drilled to target the main fault gouge-oriented ENE-WSW to a total depth of $19.5 \mathrm{~m}$. The site selection was successful to penetrate the fault gouge down to approximately $17.0 \mathrm{~m}$ depth as confirmed by the highly pulverized clay mixed with the highly weathered granitic catalysts recovered from drilling cuttings. The pumping test continued over more than 7 hours at well Asn-P with a discontinuous discharge rate of $10 \mathrm{~m}^{3} / \mathrm{h}$ to keep the groundwater level above the submersible pump and the stress rhythms are shown in Figure 11. Over 2 minutes' time from the start of pumping, the groundwater level has fallen from a depth of $2.83 \mathrm{~m}$ to $18.00 \mathrm{~m}$. Monitoring the aquifer perturbations at Asn-1, Asn-2, and Asn-3 piezometers showed no response at all indicating that the main ENE-WSW fault acts as a perfect impermeable zone to groundwater as well as the other faults cutting across it (Figure 11). The chemical analysis of the water sample collected from well Asn-P (Table 3) also showed brackish water with TDS of $2163 \mathrm{ppm}$ and significant sulphate $(23.56 \mathrm{mEqv})$ and nitrates (49.8 ppm). This clearly indicates that this percolated water is biologically contaminated and most likely attributed to leakage from the improbably constructed sewage system at the urban communities nearby the UO-site. Based on the available investigations and field observations, the prevailing groundwater flow system follows an intricate pattern of low conductive faults and joints-oriented ENE-WSW, 


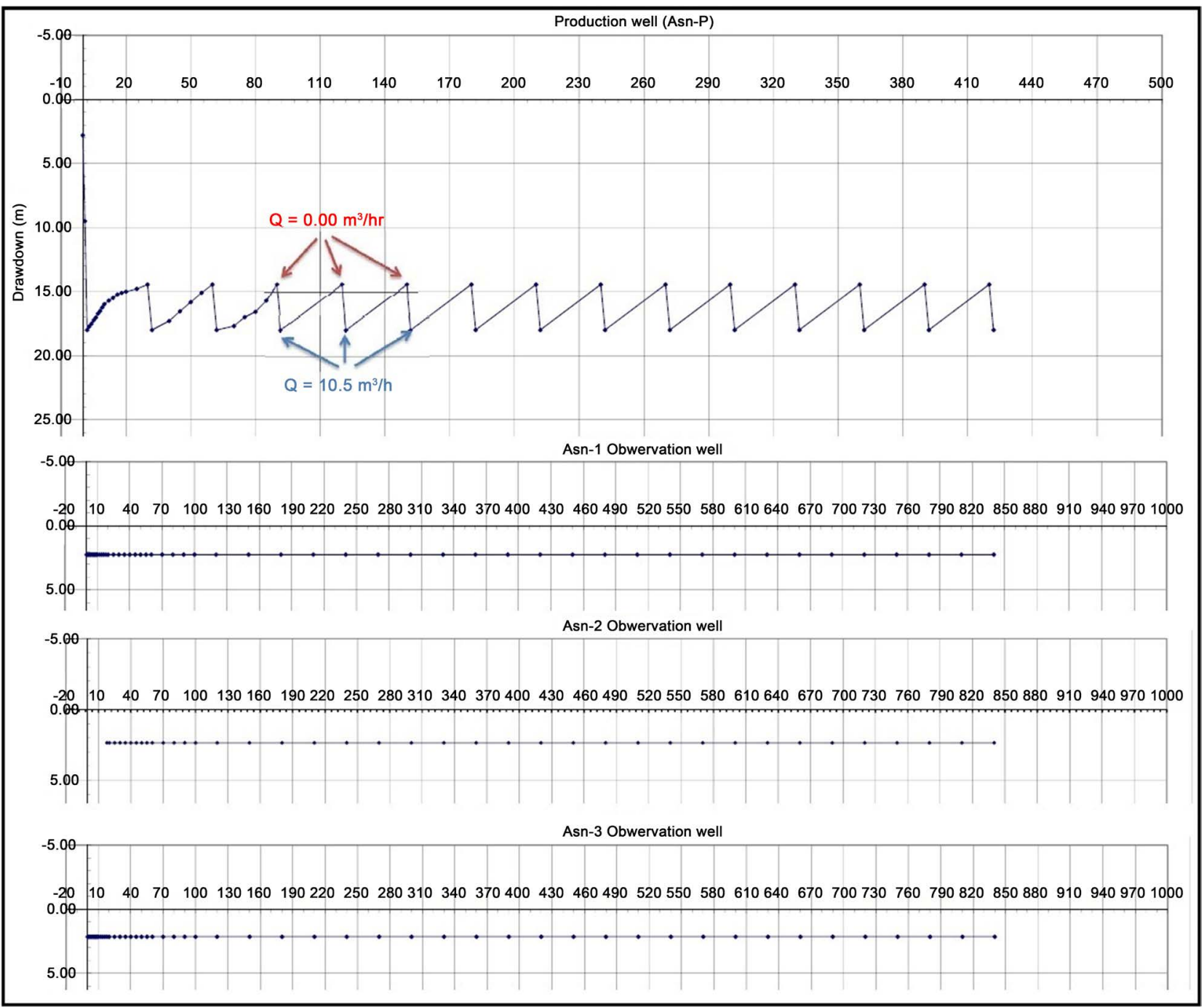

Figure 11. The aquifer stress and perturbation monitoring in piezometers Asn-1, Asn-2, and Asn-3 reported in a pumping test completed over seven hours period in the study area.

Table 3. The chemical composition (major and trace elements) of a water sample collected from the Asn-P well.

\begin{tabular}{cccc}
\hline \multicolumn{2}{c}{ Physical properties } & \multicolumn{2}{c}{ Trace elements (ppm) } \\
\hline $\mathrm{EC}$ & $\mathrm{NH}^{4+}$ & 0.14 & \\
$\mathrm{TDS}$ & $2163 \mathrm{ppm}$ & $\mathrm{NO}_{3}^{-}$ & 49.8 \\
$\mathrm{pH}$ & 7.4 & $\mathrm{~B}$ & 0.251 \\
& Anions (mEqv/l) & $\mathrm{Fe}$ & 0.161 \\
$\mathrm{CO}_{3}^{2-}$ & - & $\mathrm{Mn}$ & 0.18 \\
$\mathrm{HCO}_{3}^{-}$ & 2.08 & $\mathrm{Co}$ & 0.006 \\
$\mathrm{Cl}^{-}$ & 5 & $\mathrm{~Pb}$ & 0.028 \\
$\mathrm{SO}_{4}^{2-}$ & 23.56 & $\mathrm{Cr}$ & 0.003 \\
& $\mathrm{Cations} \mathrm{mEqv} / \mathrm{l})$ & $\mathrm{P}$ & 0 \\
$\mathrm{Ca}_{\mathrm{Mg}}^{-2}$ & 7.94 & $\mathrm{Zn}$ & 0 \\
$\mathrm{Na}$ & 3.42 & $\mathrm{Cu}$ & 0 \\
$\mathrm{~K}$ & 18.86 & $\mathrm{Cd}$ & 0 \\
\end{tabular}


NW-SE, N-S, and E-W. In addition, the weathered/fractured granite unit represents the main aquitard to which all hydrogeological responses and behaviors can be explained. This aquitard is characterized by a thick profile of fractured granite with intensively weathered zone, especially at the shallow depth, that furnishes high capacity for groundwater storage but limited in conductance. Generally, fractures control the flow regime and preferential weathering accelerates over time that ultimately results in thick weathered mantle stripping the main flow paths. Surface water is typically gathered to percolate through the significantly conductive valley fill sand and silt to the weathered/fractured granite aquitard. This aquitard is characterized by fair to medium vertical hydraulic conductivity but dominantly lacks horizontal conductivity due to the well-developed weathering and mineralization along the fault planes and/or fractures (Figure 9(b)). This may explain the preferential vertical flow and the relationship of water level in the pond to the seasonal variations in the Nile water. In addition, the dead response to the pumping stress observed in the neighboring piezometers (Figure 11) of the pumping test and the presence of separate spots of dispersed seepage also support the negligible horizontal conductivity in the fractured/weather granite aquitard. Figure 9 (c) shows a good clue to this interpretation as the salt crystals are developed around a perched water accumulation within the valley fill unit overlying the massive granite at a graveyard located up dip of the UO-site from the sewage system of the neighboring communities. In addition, the large water ponds developed over years to the north of the Aswan reservoir where large quantities of sand are quarried for the High Dam construction support this interpretation as well. Accordingly, the complex pattern of impermeable fault and fracture system hinders the use of pumping scenarios to manage the developed surface water pond or seepage, and mandates using local interactions to individual problems. Therefore, the developed water pond at the UO-site can be managed using a French trench with sump and pump to maintain the groundwater level below the ground surface and prevent further surface water accumulations or the development of seepage.

\section{Conclusion}

The present study indicated the development of a fractured granite aquitard that is dominated with ENE-WSW, NW-SE, N-S, and E-W fault/fracture systems. These systems associate fault gouges and fractures with well-developed weathering and/or mineralization along these planar fabrics. Geophysical investigations confirmed by drilling of test holes indicated the development of three main units arranged from top to bottom as: valley fill unit (1.0 - $15 \mathrm{~m}$ thick), medium fractured to weathered unit ( 2.5 - $10 \mathrm{~m}$ thick), and massive to slightly fractured granite of 2.5 - $10.0 \mathrm{~m}$ thick. The aquifer test monitored at three observation wells reported no responses to the aquifer stress during 7 hours pumping at the nearby production well ( 5 - $10 \mathrm{~m}$ away), indicating very limited transmissivity with an irregular preferential vertical flow system. Such observations indicate tight 
groundwater system with negligible hydraulic conductivity, which hinders applications of aquifer stress or pumping scenarios. Alternatively, the application of local covered drainage system with sump and pump presents the optimum technique to control the local groundwater accumulations and seepage near the UO-site.

\section{Acknowledgements}

The author very much acknowledges the generous support received from the Supreme Council of Antiques to complete this work and appreciates the kind approval to publish the results and findings. Special thanks are directed to Prof. Dr. Maher A. El Amawy and Prof. Dr. Mohamed G. Bhairy for the unlimited support in data acquisition, preliminary interpretation, and the insightful suggestions. The support from the Center of Environmental and Archeological Engineering, Faculty of Engineering, Cairo University, especially Eng. Fathi Ahmed and Eng. Mohamed Hommos is highly cherished.

\section{Conflicts of Interest}

The author declares no conflicts of interest regarding the publication of this paper.

\section{References}

[1] Maréchal, J.C., Dewandel, B. and Subrahmanyam, K. (2004) Use of Hydraulic Tests at Different Scales to Characterize Fracture Network Properties in the Weathered-Fractured Layer of a Hard Rock Aquifer: Fracture Network Properties in Hard Rock. Water Resources Research, 40, 1-17. https://doi.org/10.1029/2004WR003137

[2] Rangarajan, R. and Athavale, R.N. (2000) Annual Replenishable Ground Water Potential of India: An Estimate Based on Injected Tritium Studies. Journal of Hydrology, 234, 38-53. https://doi.org/10.1016/S0022-1694(00)00239-0

[3] Deyassa, G., Kebede, S., Ayenew, T. and Kidane, T. (2016) Crystalline Basement Aquifers of Ethiopia: Their Genesis, Classification and Aquifer Properties. Journal of African Earth Sciences, 100, 191-202. https://doi.org/10.1016/j.jafrearsci.2014.06.002

[4] National Research Council (1996) Rock Fractures and Fluid Flow: Contemporary Understanding and Applications. National Academy Press, Washington, DC, 551 p.

[5] Vidstrand, P. (2001) Comparison of Upscaling Methods to Estimate Hydraulic Conductivity. Ground Water, 39, 401-407. https://doi.org/10.1111/j.1745-6584.2001.tb02324.x

[6] Shapiro, A.M., Hsieh, P.A., Burton, W.C. and Walsh, G.J. (2007) Integrated Multi-Scale Characterization of Ground-Water Flow and Chemical Transport in Fractured Crystalline Rock at the Mirror Lake Site, New Hampshire. In: Hyndman, D.W., Day-Lewis, F.D. and Singha, K., Eds., Subsurface Hydrology: Data Integration for Properties and Processes, American Geophysical Union, Washington DC, 201-226.

[7] Shapiro, A.M., Ladderud, J.A. and Yager, R.M. (2015) Interpretation of Hydraulic Conductivity in a Fractured-Rock Aquifer over Increasingly Larger Length Dimen- 
sions. Hydrogeology Journal, 23, 1319-1339.

https://doi.org/10.1007/s10040-015-1285-7

[8] Sukhija, B.S., Reddy, D.V., Nagabhushanam, P., et al. (2006) Characterization of Recharge Processes and Groundwater Flow Mechanisms in Weathered-Fractured Granites of Hyderabad (India) Using Isotopes. Hydrogeology Journal, 14, 663-674. https://doi.org/10.1007/s10040-005-0461-6 https://link.springer.com/article/10.1007/s10040-005-0461-6

[9] Guihéneuf, N., Boisson, A. and Bour, O. (2014) Groundwater Flows in Weathered Crystalline Rocks: Impact of Piezometric Variations and Depth-Dependent Fracture Connectivity. Journal of Hydrology, 511, 320-334. https://doi.org/10.1016/j.jhydrol.2014.01.061

[10] Boisson, A., Guihéneuf, N., Perrin, J., Bour, O., Dewandel, B., Dausse, A., Viossanges, M., Ahmed, S. and Maréchal, J.C. (2015) Determining the Vertical Evolution of Hydrodynamic Parameters in Weathered and Fractured South Indian Crystalline Rocks Aquifers: Insights from a Study on an Instrumented Site. Hydrogeology Journal, 23, 757-773. https://doi.org/10.1007/s10040-014-1226-x

[11] Drew, L., Shuenemeyer, J., Armstrong, T. and Sutphin, D. (2001) Initial Yield to Depth Relation for Water Wells Drilled into Crystalline Bedrocks: Pinardville Quadrangle, New Hampshire. GroundWater, 39, 676-684. https://doi.org/10.1111/j.1745-6584.2001.tb02357.x

[12] Perrin, J., Ahmed, S. and Hunkeler, D. (2011) The Effects of Geological Heterogeneities and Piezometric Fluctuations on Groundwater Flow and Chemistry in a Hard-Rock Aquifer, Southern India. Hydrogeology Journal, 19, 1189-1201. https://doi.org/10.1007/s10040-011-0745-y

[13] Dewandel, B., Alazard, M., Lachassagne, P., Bailly-Comte, V. and Wyns, R. (2017) Respective Roles of the Weathering Profile and the Tectonic Fractures in the Structure and Functioning of Crystalline Thermo-Mineral Carbo-Gaseous Aquifers. Journal of Hydrology, 547, 690-707. https://doi.org/10.1016/j.jhydrol.2017.02.028

[14] Anaba Onana, A.B., Ndam Ngoupayou, J.R. and Mvondo Ondoa, J. (2017) Analysis of Crystalline Bedrock Aquifer Productivity: Case of Central Region in Cameroon. Groundwater for Sustainable Development, 5, 66-74.

https://doi.org/10.1016/j.gsd.2017.05.003

[15] Bakundukize, C., Mtoni, Y., Martens, K., Van Camp, M. and Walraeven, K. (2016) Poor Understanding of the Hydrogeological Structure Is a Main Cause of Hand-Dug Wells Failure in Developing Countries: A Case Study of a Precambrian Basement Aquifer in Bugesera Region (Burundi). Journal of African Earth Sciences, 121, 180-199. https://doi.org/10.1016/j.jafrearsci.2016.05.025

[16] Oladunjoye, M.A., Adefehinti, A. and Ganiyu, K.A.O. (2019) Geophysical Appraisal of Groundwater Potential in the Crystalline Rock of Kishi Area, Southwestern Nigeria. Journal of African Earth Sciences, 151, 107-120.

https://doi.org/10.1016/j.jafrearsci.2018.11.017

[17] Herczeg, A.L. and Leaney, F.W. (2011) Review: Environmental Tracers in Arid Zone Hydrology. Hydrogeology Journal, 19, 17-29. https://doi.org/10.1007/s10040-010-0652-7

[18] Leketa, K., Abiye, T., Zondi, S. and Butler, M. (2019) Assessing Groundwater Recharge in Crystalline and Karstic Aquifers of the Upper Crocodile River Basin, Johannesburg, South Africa. Groundwater for Sustainable Development, 8, 31-40. https://doi.org/10.1016/j.gsd.2018.08.002

[19] Pettenati, M., Picot-Colbeaux, G., Thiéry, D., Boisson, A. and Kloppmann, W. 
(2014) Water Quality Evolution During Managed Aquifer Recharge (MAR) in Indian Crystalline Basement Aquifers: Reactive Transport Modeling in the Critical Zone. Procedia Earth and Planetary Science, 10, 82-87. https://doi.org/10.1016/j.proeps.2014.08.016

[20] Walraevens, K., Bakundukize, C., Mtoni, Y.E. and Van Camp, M. (2018) Understanding the Hydrogeochemical Evolution of Groundwater in Precambrian Basement Aquifers: A Case Study of Bugesera Region in Burundi. Journal of Geochemical Exploration, 188, 24-42. https://doi.org/10.1016/j.gexplo.2018.01.003

[21] Ammar, A.I. and Kruse, S.E. (2016) Resistivity Soundings and VLF Profiles for Siting Groundwater Wells in a Fractured Basement Aquifer in the Arabian Shield, Saudi Arabia. Journal of African Earth Sciences, 116, 56-67. https://doi.org/10.1016/j.jafrearsci.2015.12.020

[22] Tiedeman, C.R., Goode, D.J. and Hsieh, P.A. (1998) Characterizing a Ground Water basin in a New England Mountain and Valley Terrain. Ground Water, 36, 611-620. https://doi.org/10.1111/j.1745-6584.1998.tb02835.x

[23] Yager, R.M., Voss, C.I. and Southworth, S. (2009) Comparison of Alternative Representations of Hydraulic-Conductivity Anisotropy in Folded Fractured-Sedimentary Rock: Modeling Groundwater Flow in the Shenandoah Valley (USA). Hydrogeology Journal, 17, 1111-1131. https://doi.org/10.1007/s10040-008-0431-x

[24] Cushman, J.H., Bennethum, L.S. and Hu, B.X. (2002) A Primer on Upscaling Tools for Porous Media. Adv. Water Resources, 25, 1043-1067. https://doi.org/10.1016/S0309-1708(02)00047-7

[25] Kruseman, G.P. and de Ridder, N.A. (1990) Analysis and Evaluation of Pumping Test Data, 2nd edn, International Institute for Land Reclamation and Improvement, Wageningen, The Netherlands, $377 \mathrm{p}$.

[26] Shapiro, A.M. and Hsieh, P.A. (1998) How Good Are Estimates of Transmissivity from Slug Tests in Fractured Rock. GroundWater, 36, 37-48. https://doi.org/10.1111/j.1745-6584.1998.tb01063.x

[27] Sanchez-Vila, X., Guadagnini, A. and Carrera, J. (2006) Representative Hydraulic Conductivities in Saturated Groundwater Flow. Reviews of Geophysics, 44, RG3002. https://doi.org/10.1029/2005RG000169

[28] Tiedeman, C.R. and Hsieh, P.A. (2001) Assessing an Open-Well Aquifer Test in Fractured Crystalline Rock. GroundWater, 39, 68-78. https://doi.org/10.1111/j.1745-6584.2001.tb00352.x

[29] El-Sehily, B.M. (2016) Fracture Mechanics in Ancient Egypt. Procedia Structural Integrity, 2, 2921-2928. https://doi.org/10.1016/j.prostr.2016.06.365

[30] Habachi, L. (1906) The Obelisks of Egypt, Skyscrapers of the Past. Charles Scribner's Sons, New York.

[31] Engelbach, R. (1922) The Aswan Obelisk with Some Remarks on the Ancient Engineering. Imprimerie de L'Institut Francais D'Archeologie Orientale, Cairo, 1-47.

[32] Engelbach, R. (1923) The Problem of the Obelisks, from a Study of the Unfinished obelisk at Aswan. T. F. Unwin Ltd., London, 134 p.

[33] Engelbach, R. (1938) The Quarries of the Western Nubian Desert and the Ancient Road to Tushka. Annals du Service des Antiquities de P Egypte, 38, 369-390.

[34] Klemm, R. and Klemm, D.D. (1993) Steine und Steinbrüche im Alten Ägypten, Springer-Verlag, Berlin, 465 p. https://doi.org/10.1007/978-3-642-77027-2

[35] Klemm, R. and Klemm, D.D. (2008) Stones and Quarries in Ancient Egypt, British 
Museum Press, London, 354 p.

[36] Abdulaziz, A.M., Hurtado, J.M. and Al-Douri, R. (2009) Application of Multitemporal Landsat Data to Monitor Land Cover Changes in the Eastern Nile Delta Region, Egypt. International Journal of Remote Sensing, 30, 2977-2996. https://doi.org/10.1080/01431160802558675

[37] Knapp, K.C. and Franklin, B. (2019) Groundwater Usage and Management: Common Property, Efficiency, and Sustainability. Water Resources and Economics, 27, Article No. 100135. https://doi.org/10.1016/j.wre.2019.01.001

[38] Mohamed, H.H., Mukhopadhyay, S. and Sharma, J. (2010) Attenuation of Coda Waves in the Aswan Reservoir Area, Egypt. Tectonophysics, 492, 88-98. https://doi.org/10.1016/j.tecto.2010.05.018

[39] Sobeih, M.M., El-Arabi, N.E., Helal, E.Y. and Awad, B.S. (2017) Management of Water Resources to Control Groundwater Levels in the Southern Area of the Western Nile Delta, Egypt. Water Science, 31, 137-150. https://doi.org/10.1016/j.wsj.2017.09.001

[40] Abdulaziz, A.M., Hurtado Jr., J.M. and Faid, A.M. (2012) Hydrogeological Characterization of Gold Valley: An Investigation of Precipitation Recharge in an Intermountain Basin in the Death Valley Region, California, USA. Hydrogeology Jour nal, 20, 701-718. https://doi.org/10.1007/s10040-012-0840-8

[41] Abdulaziz, A.M. and Faid, A.M. (2017) Aquifer Characterization and Groundwater Potential Using Integrated Geoelectric Sounding and Geoinformatics in West Maghagha Area, Minia Governorate, Egypt. Open Journal of Geology, 7, 1625-1643. https://doi.org/10.4236/ojg.2017.711109

[42] Lai, W.W., Dérobert, X. and Anna, P. (2018) A Review of Ground Penetrating Radar Application in Civil Engineering: A 30-Year Journey from Locating and Testing to Imaging and Diagnosis. NDT \& E International, 96, 58-78. https://doi.org/10.1016/j.ndteint.2017.04.002

[43] Barseem, M., El Sayed, A. and Youssef, A. (2013) Impact of Geologic Setting on the Groundwater Occurrence in Wadis El Sanab, Hashem, and Khrega Using Geoelectrical Methods-Northwestern Coast: Egypt. Arabian Journal of Geoscience, 7, 5127-5139. https://doi.org/10.1007/s12517-013-1129-5

[44] Abdulaziz, M.A. (2014) Hydrostratigraphic Characterization of Groundwater Systems in Khatatba Area Using Vertical Electrical Sounding and Well Log Data, SW Nile Delta, Egypt. International Journal of Advancement in Earth and Environmental Sciences, 2, 39-50. 